\title{
BARIÉRY ELEKTRONICKÉHO OBCHODOVANIA - PREVÁDZKOVATELIA ELEKTRONICKÉHO OBCHODOVANIA VERZUS PREVÁDZKOVATELIA KAMENNÝCH OBCHODOV
}

\author{
Eva Gavláková*
}

\section{Úvod}

Najpoužívanejšími výrazmi posledných dvoch rokov, ktoré sa udomácnili nie len v ekonomických kruhoch, ale poznačili aj mnohé rodiny, sú slová ako hospodárska kríza, prepúšt’anie, krach vel'kých či malých podnikov a vysoká miera nezamestnanosti. Ponuka práce sa znížila a mnohé podniky v rámci šetrenia spustili hromadné prepúšt’anie. O prácu dôsledkom hospodárskej krízy prišlo niekol'ko tisíc l'udí. Vidina nového zamestnania nebola vel'mi pozitívna. Jednou z možných variant riešenia problému nezamestnanosti, je vlastné podnikanie, ktoré je dnes podporované aj zo strany štátu.

Začínajúci podnikatel' rozmýšl'a, v prvom rade nad nízkymi vstupnými nákladmi a vysokými výstupmi v podobe zisku. Takéto riešenie ponúka oblast' elektronického obchodovania. Nie sú k nemu potrebné takmer žiadne kancelárske priestory. Elektronický obchod je možné prevádzkovat' z pohodlia bytu alebo domu, čo šetrí náklady za prenájom kancelárskych, skladových či prevádzkových priestorov. Základnými prostriedkami začínajúceho podnikatel'a sú počítač, pripojenie na internet a dobrý podnikatel'ský zámer. Túto formu obchodovania samozrejme môže využívat' podnik rôznej vel'kosti a podnikatel'ského zamerania. Na základe charakteristiky elektronického obchodovania je možné predpokladat', že najčastejšie využíva túto formu sektor malého a stredného podnikania, ktorý tvoria mikropodniky, malé a stredné podniky. Výsledky vykonaného prieskumu tento fakt potvrdili.

\section{Elektronické obchodovanie na Slovensku v sektore malého a stredného podnikania}

Elektronické obchodovanie $\mathrm{v}$ našich podmienkach sa stáva čoraz viac populárnym. Za účelom zistenia základných bariér, s ktorými sa stretli prevádzkovatelia elektronického obchodu pri jeho zavádzaní a samotnej prevádzke bol uskutočnený prieskum. Boli oslovené spoločnosti, ktoré prevádzkujú elektronický obchod, firmy, ktoré majú len webovú prezentáciu svojej firmy a podniky, ktoré vôbec nevyužívajú internet na propagáciu.

Z oslovených 122 respondentov prevádzkuje elektronický obchod 51, s rôznym podnikatel'ský zameraním. Najrozšírenejším je samozrejme obchodná činnost', najmenej podniká v oblasti poskytovania peňažných služieb (pozri Obrázok 1.).

\footnotetext{
* Ing. Eva Gavláková., Žilinská univerzita v Žiline, Fakulta prevádzky a ekonomiky dopravy a spojov, Katedra spojov, Univerzitná 1, 01026 Žilina e-mail: eva.gavlakova@fpedas.uniza.sk
} 


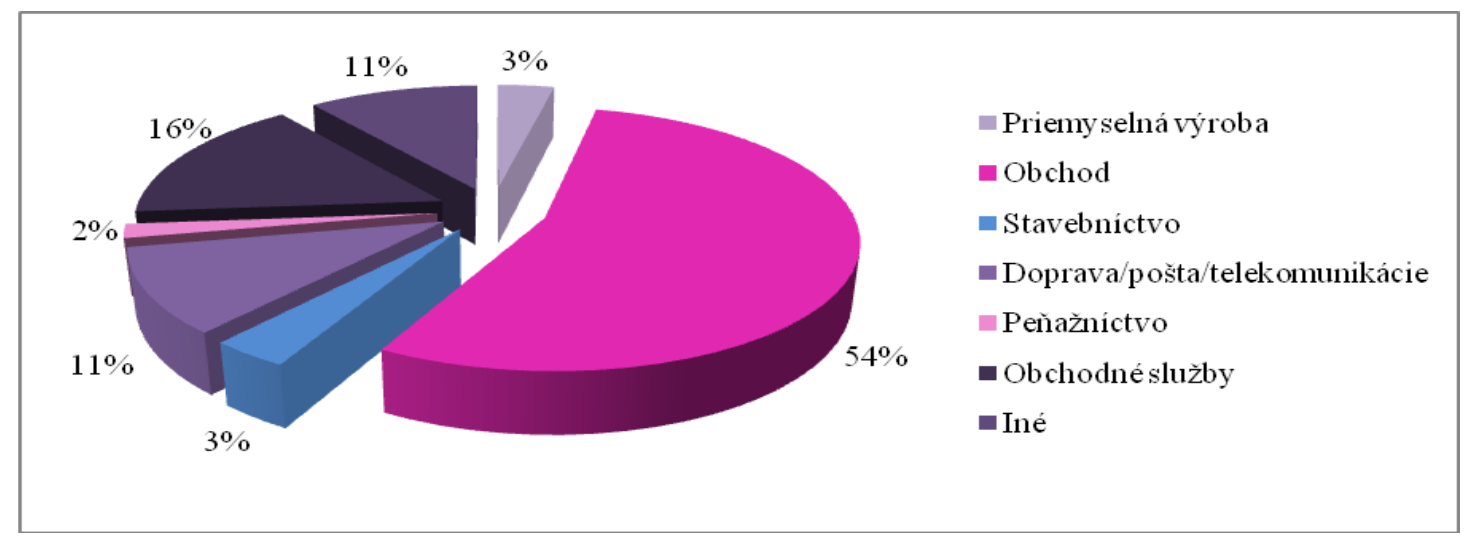

Obrázok 1. Druhy elektronického obchodu podl'a podnikatel'skej činnosti

Najzastúpenejšou skupinou z oslovených podnikov, ktoré prevádzkujú elektronické obchodovanie, boli mikropodniky (49 \%), druhou bola skupina živnostníkov (22 \%), malé podniky (18\%), stredné podniky (8\%) a vel'ké podniky (3\%). Pri kategorizácií mikropodnikov, malých a stredných podnikov predpokladáme, že ide o obchodné spoločnosti, ako napr. spoločnosti s ručením obmedzeným a akciové spoločnosti. Táto forma podnikania sa pri výbere vzorky respondentov vyskytovala najčastejšie.

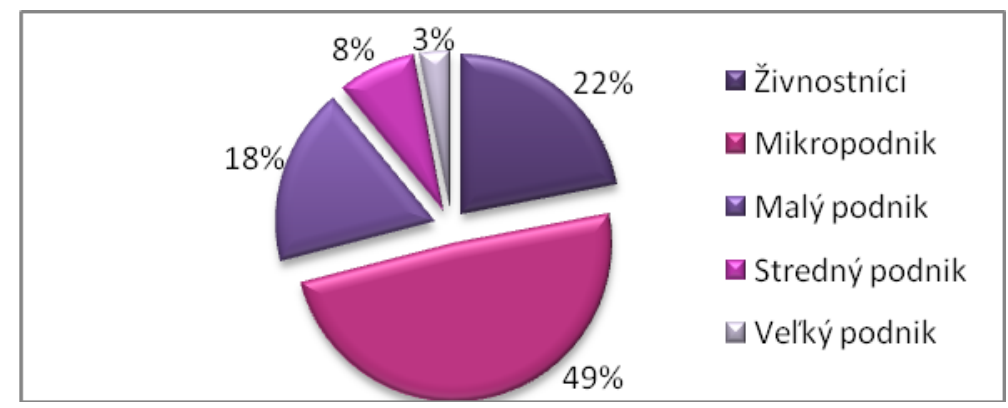

Obrázok 2. Prieskum elektronického obchodovania - vel'kostná kategória podniku

Malé a stredné podnikanie je charakteristické úzkou špecializáciou výroby, resp. poskytovania služieb, čo im zabezpečuje dynamickú a efektívnu odozvu na zmeny v dopyte. Môžu pružne reagovat' na zmeny v požiadavkách zákazníkov a rýchlo inovovat' produkt, podl'a ich potrieb. Vel'akrát ide o firmy, ktoré majú úzky vzt’ah so zamestnancami alebo o rodinné firmy, ktoré zabezpečujú úsporu v oblasti financií.

Do prieskumu sa zapojili aj firmy zo zahraničia, kde 29 \% tvorili respondenti z Českej republiky a $3 \%$ z iných štátov. Slovenská republika mala zastúpenie zo všetkých krajov, a to v pomere 15 \% Žilinský a Nitriansky kraj, 13 \% Bratislavský kraj, 11 \% Trenčiansky kraj, 10 \% Trnavský kraj, 8 \% Košický kraj, 7 \% Prešovský kraj a 6 \% Banskobystrický kraj.

Výsledky prieskumu poukázali na základné bariéry, ktoré vnímajú podnikatelia pri zavádzaní a prevádzkovaní elektronického obchodu. Na samotnom začiatku akejkol'vek činnosti je nápad. Ten je potrebné prepracovat' do podnikatel'ského zámeru, pri ktorom je prvoradé určit' predmet podnikania. Najčastejším predmetom podnikania oslovených respondentov, prevádzkujúcich elektronické obchodovanie je obchod (61 \%) a obchodné služby (12 \%). Nikto nepodniká v oblasti poskytovania hotelových, reštauračných, pohostinských služieb, pol'nohospodárstva a potravinárskej výroby. Týmto sa potvrdzuje fakt, že nie všetko sa dá predávat' prostredníctvom internetu. Aj ked' forma elektronického obchodovania v oblasti hotelových služieb je dnes vo vel'kej miere využívaná. Zákazníkovi stačí na internetovej stránke príslušného hotela využit' dostupnú službu on-line rezervácie. Po vyplnení objednávkového formulára a zaplatení celkovej sumy, je spätne na zákazníkov e mail odoslaný voucher, ktorý plní funkciu dokladu o zaplatení a rezervovaní. Pre 
zabezpečenie konkurencieschopnosti je dôležité príst' na trh s niečím novým, výnimočným. Možným variantom je využit' sektor, ktorý v rámci elektronického obchodovania nemá žiadnu, poprípade minimálnu konkurenciu.

\section{Bariéry elektronického obchodovania}

Zaujímavé závislosti je možné sledovat' pri vyhodnotení bariér prevádzkovatel'mi a obchodníkmi, ktorí využívajú internetovú stránku len na prezentáciu svojej firmy a predmetu činnosti (Obrázok 3).

Tabul'ka 1. Bariéry ovplyvňujúce podnikanie v oblasti elektronického obchodovania

\begin{tabular}{|l|c|r|r|}
\hline $\begin{array}{l}\text { Bariéry ovplyvňujúce podnikanie v oblasti elektronického } \\
\text { obchodovania }\end{array}$ & $\begin{array}{l}\text { Ozn. } \\
\text { Skupiny }\end{array}$ & $\begin{array}{l}\text { Klasickí } \\
\text { obchodníci }\end{array}$ & $\begin{array}{l}\text { Prevádzkovatelia } \\
\text { e-obchodu }\end{array}$ \\
\hline Nevhodnost' produktov pre e - obchod & A & $54 \%$ & $33 \%$ \\
\hline Zákazníci nechcú nakupovat' cez e - obchod & B & $10 \%$ & $23 \%$ \\
\hline Bezpečnost' platieb a uzatvárania obchodu & C & $26 \%$ & $26 \%$ \\
\hline Nejasná legislatíva & E & $21 \%$ & $28 \%$ \\
\hline Reorganizácia obchodných postupov & F & $9 \%$ & $9 \%$ \\
\hline $\begin{array}{l}\text { Nízka informovanost' o možnostiach elektronického } \\
\text { podnikania }\end{array}$ & G & $21 \%$ & $42 \%$ \\
\hline $\begin{array}{l}\text { Nízka propagácia firiem poskytujúce kompletný servis } \\
\text { zavádzania e - obchodu }\end{array}$ & H & $12 \%$ & $28 \%$ \\
\hline $\begin{array}{l}\text { Nepriaznivé skúsenosti s elektronickým predajom } \\
\text { v minulosti }\end{array}$ & I & $12 \%$ & $21 \%$ \\
\hline Vysoké náklady na vývoj aplikácií elektronického obchodu & J & $10 \%$ & $19 \%$ \\
\hline Nedostatok skúseností so zavádzaním & K & $19 \%$ & $26 \%$ \\
\hline Iné bariéry & L & $4 \%$ & $7 \%$ \\
\hline
\end{tabular}

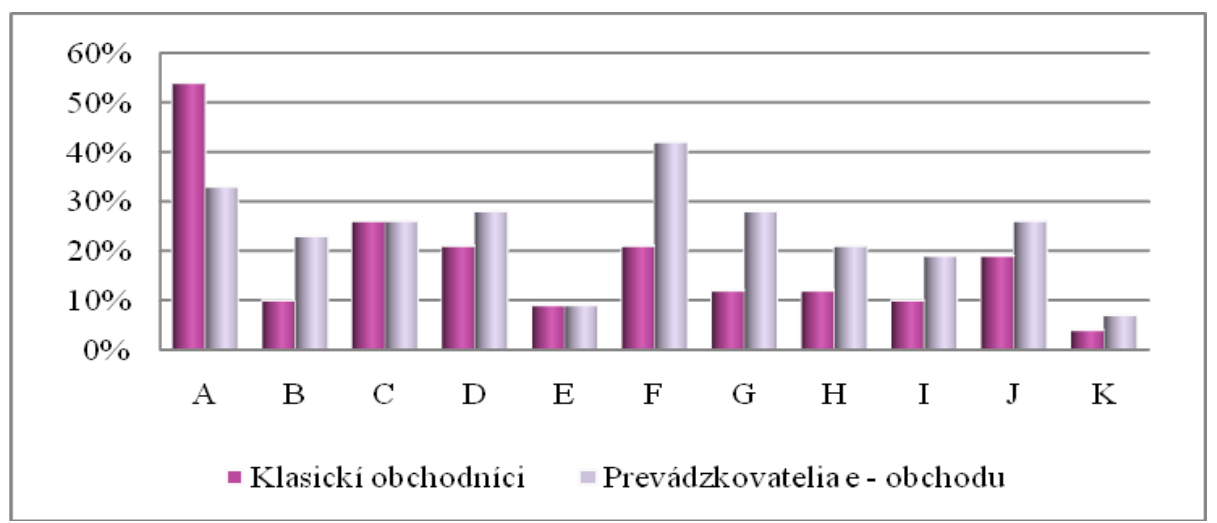

Obrázok 3. Bariéry ovplyvňujúce podnikanie v oblasti elektronického obchodovania z pohl’adu ich prevádzkovatel'ov a klasických obchodníkov (zdroj Tabul'ka 6.)

Prevádzkovatelia e - obchodu berú za najväčší problém nízku informovanost' o možnostiach elektronického obchodovania (42 \%). Na druhej strane tí, ktorí ho ešte neprevádzkujú vidia najväčšiu bariéru v tom, že ich produkty nie sú vhodné pre elektronické obchodovanie (54\%). Z toho vyplýva, že skutočne niekedy sami seba presvedčíme, že sa niečo nedá a vzdáme to skôr, ako by sme to vyskúšali. Na druhej strane $23 \%$ prevádzkovatel'ov poukázalo na neochotu zo strany zákazníkov nakupovat' týmto spôsobom, 
pričom len $10 \%$ klasických obchodníkov, pokladá túto možnost' za bariéru elektronického obchodovania. Faktory, ktoré ovplyvňujú nákupné správanie zákazníka v elektronickom obchode sú rôzne. Internet nedokáže sprostredkovat' vôňu, chut' alebo kvalitu ponúkaného tovaru. Preto zákazníci pri určitých špecifických druhoch produktov alebo služieb uprednostňujú klasický spôsob výberu a nákupu.

Najčastejšie kritizovaným faktorom, ktorý negatívne ovplyvňuje rozvoj elektronického obchodovania je nejasná a nejednotná legislatíva, upravujúca tento druh obchodovania a podnikania, v rámci celej Európskej únie. Tento fakt potvrdili aj oslovení respondenti. 21 \% tých, ktorí neprevádzkujú elektronické obchodovanie poukázalo na nejasnú legislatívnu informovanost' a podporu tohto druhu podnikania. $28 \%$ prevádzkovatel'ov tento fakt skutočne pocit’uje. Elektronické obchodovanie a podnikanie, ako také, nie je dostatočne jednotné, v zmysle jasného a jednoznačného vymedzenia práv a povinností prevádzkovatel'a a spotrebitel'a tohto druhu podnikania. Pre začínajúceho podnikatel'a je predstava študovat' všetky zákony, ktoré sa dotýkajú elektronického obchodovania odstrašujúca. Preto by bolo vhodné vytvorit' ucelený právny rámec pre túto oblast'. Obe skupiny respondentov, t. j. prevádzkovatelia elektronického obchodu a klasickí obchodníci sú jednotní v problematike bezpečnosti platieb a uzatvárania obchodu (26\%).

Zaujímavý je ten fakt, že $28 \%$ prevádzkovatel'ov elektronického obchodovania sa stretli s nízkou propagáciou firiem, ktoré poskytujú kompletný servis zavedenia e - obchodu. Tento fakt vníma za negatívny len 12 \% z klasických obchodníkov. Väčšina firiem, ktoré poskytujú kompletný vývoj a implementáciu systému e - obchodovania, využíva na svoje spropagovanie najčastejšie registráciu v dostupných internetových katalógoch firiem, alebo si zabezpečia popredné miesta $\mathrm{v}$ internetových prehliadačoch.

\section{Prínosy elektronického obchodovania}

Prevádzkovatelia elektronického obchodu v prieskume vyzdvihli a poukázali na pozitívne prínosy jeho zavedenia do ich podnikatel'skej činnosti. Až $73 \%$ opýtaných označilo za najväčší prínos zvýšenie počtu zákazníkov, 61 \% prístup k novým trhom, 59 \% zvýšenie predaja, 55 \% nárast tržieb a urýchlenie vybavovania objednávok, 39 \% zníženie nákladov na prevádzku telefónnych hovorov, 35 \% poukazuje na rýchlejšiu obsluhu zákazníkov, 29 \% sa znížili transakčné náklady, 27 \% umožnilo zavedenie elektronického obchodovania redukciu zásob a 20 \% umožnil užší kontakt so zákazníkmi. V rámci iných prínosov poukázali na možnost' podrobného informovania o vlastnostiach jednotlivých výrobkov, ktoré sa z bežných printových cenníkov a letákov nedajú vyčítat' (Obrázok 4).

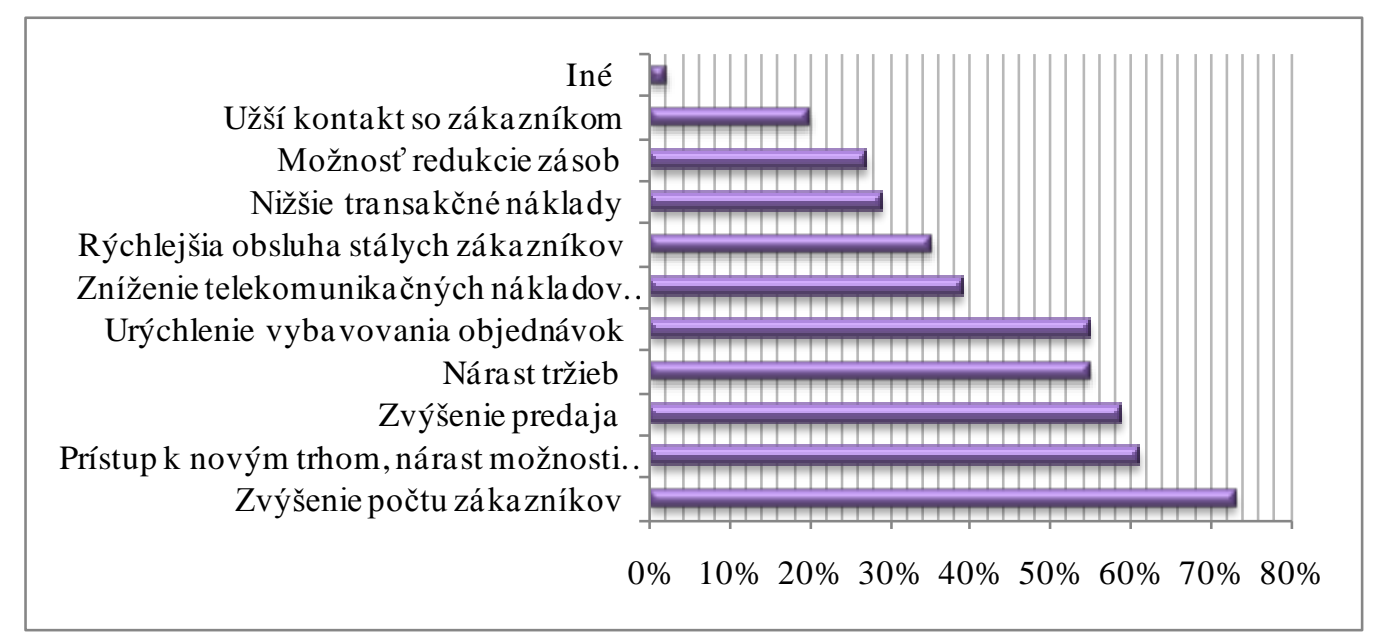

Obrázok 4. Prínosy zavedenia elektronického obchodovania pre podnikatel’ov 
Prevádzkovatelia elektronického obchodovania poukazujú na nutnost' dostatočne premysleného personálneho zabezpečenia prevádzky podnikania ako takého, a to hlavne $\mathrm{v}$ delegovaní úloh pre obsluhu podnikového systému elektronického obchodu (IT prevádzka, spracovanie objednávok, fakturácia, účtovníctvo, balenie, distribúcia, správa elektronického obchodu, aktualizácia jeho obsahu a podobne). Ked’že elektronický obchod poskytuje nové možnosti podnikania a prístup na nové trhy, treba rátat's možnost'ou vol'by iného ako slovenského jazyka, v ktorom sa zobrazí obsah elektronického obchodu, t. z. dostatočne sa pripravit' na odstránenie jazykovej bariéry. Vhodným riešením je mat' stránku elektronického obchodu k dispozícií minimálne vanglickom jazyku. Najväčším prínosom pre vybranú vzorku malého a stredného podnikania, ktorý v našom prípade tvoria živnostníci a mikro podniky, je podl'a výsledkov prieskumu zvýšenie počtu zákazníkov, možnost' prístupu na nové trhy, ktoré im zvyšujú objem predaja, čo sa priamou úmerou premietne v hospodárskom výsledku. Zintenzívňuje efektivitu a rýchlost' vo vybavovaní objednávok, čím sa zlepšuje starostlivost' o zákazníka v otázke promptnosti jeho obsluhy. Elektronické obchodovanie, na druhej strane znižuje prevádzkové, telekomunikačné, personálne alebo skladové náklady.

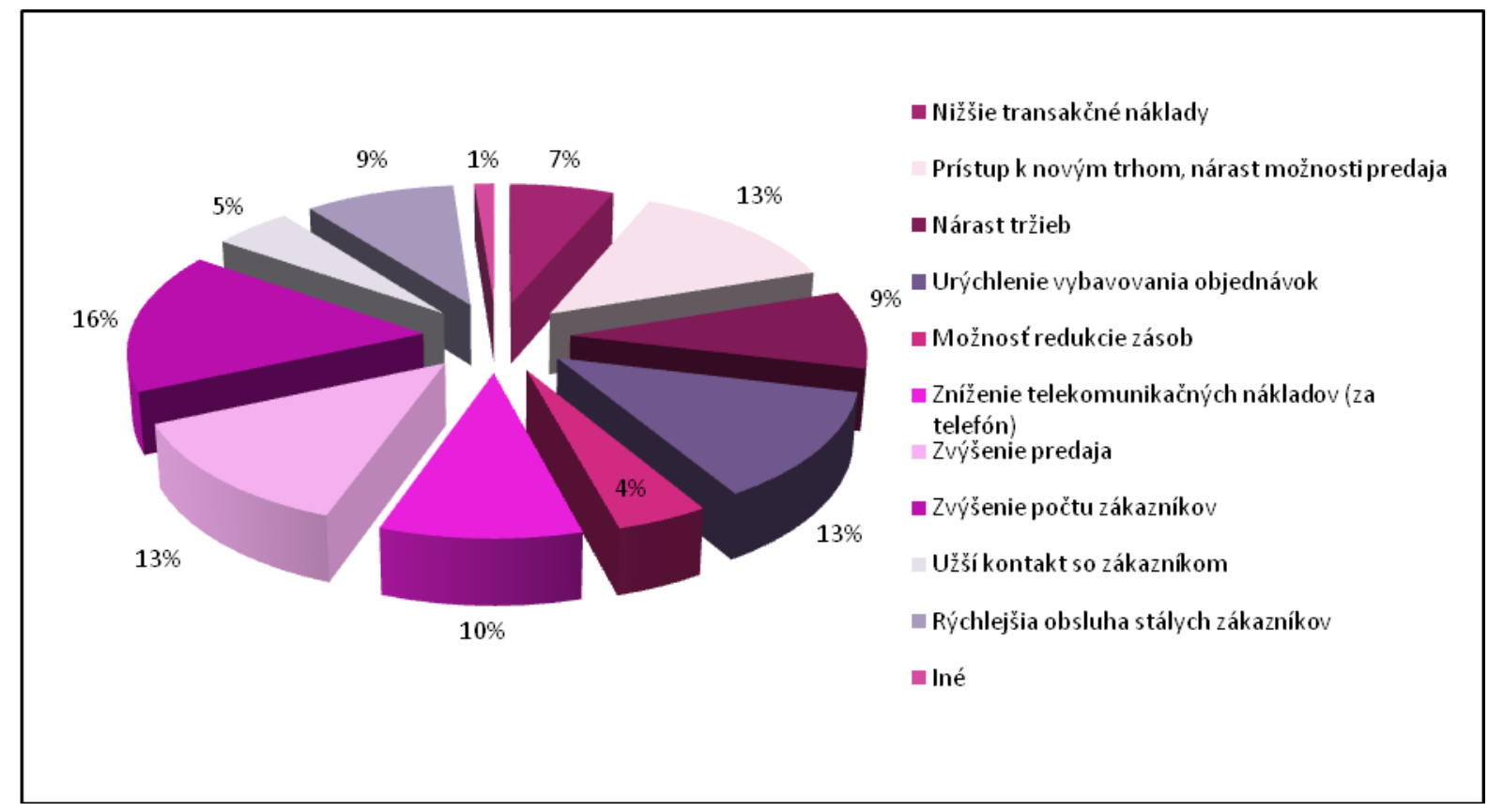

Obrázok 5. Výhody zavedenia elektronického obchodu pre skupinu živnostníkov a mikropodniky

\section{Záver}

Pri celkovom zhodnotení výsledkov prieskumu a porovnania odpovedí „klasických“ obchodníkov a prevádzkovatel'ov elektronického obchodovania, môžeme predpokladat', že hodnotenia bariér vnímané samotnými prevádzkovatel'mi, môžu byt' ovplyvnené časovým obdobím, kedy elektronický obchod zavádzali a začali prevádzkovat'. Podmienky elektronického obchodovania sa $\mathrm{v}$ priebehu posledných rokov zmenili a v súčasnosti napredujú rýchlym tempom. Keby sme porovnali vývoj elektronického obchodovania na Slovensku za posledných 10 rokov, uvidíme obrovské rozdiely. Najviac citel’né zmeny sú v oblasti vývoja informačno - komunikačných technológií, ktoré prichádzajú každý rok s niečím novým. Popularita elektronického obchodu a jeho rozvoj, si získal svojich priaznivcov a nadšencov $\mathrm{v}$ priebehu posledných rokov. Tento fakt môže byt' dôsledkom negatívnych odpovedí oslovených respondentov prevádzkujúcich elektronické obchodovanie. Podkladmi pre moju hypotézu, sú konkrétne výsledky bariér vnímaných samotnými 
prevádzkovatel'mi. Za negatívny faktor pokladajú aj nedostatok skúseností so zavedením e obchodu (26\%), vysoké náklady na vývoj jeho aplikácií (19\%), nepriaznivé skúsenosti s týmto druhom obchodu v minulosti $(21 \%)$, či reorganizácia obchodných procesov $(9 \%)$, pričom tieto bariéry skupina klasických obchodníkov nevníma tak kriticky.

Dôvodom negatívnych odpovedí prevádzkovatel'ov elektronického obchodu môže byt' aj v tom, že si ho vytvárali vo vlastnej réžií, s tým, že nemali dostatok technických zručností, čo v konečnom dôsledku uznalo $26 \%$ oslovených účastníkov prieskumu. Dôkazom tohto tvrdenia je aj fakt, že na otázku akým spôsobom prevádzkujú webovú stránku, odpovedalo 45 \%, že vlastnými prostriedkami na cudzom serveri, 35 \% prostredníctvom outsourcingovej firmy, $18 \%$ vlastnými prostriedkami na vlastnom serveri a $1 \%$ používa kombináciu posledných dvoch spomínaných spôsobov. Implementácia elektronického obchodu nie je jednoduchá záležitost' a vyžaduje si istú dávku technických, programátorských, praktických či dizajnových zručností. Ak ich podnikatel' nemá, mal by sa obrátit' na špecializovanú firmu, ktorá mu zabezpečí stopercentne fungujúci elektronický obchod, splńajúce všetky jeho požiadavky.

\section{Literatúra}

[1] GAVLÁKOVÁ, E.: : Návrh metodickej pomôcky pre implementáciu elektronického obchodovania pre oblast' malého a stredného podnikania, Diplomová práca, 20/2010 KS, Katedra spojov, ŽU Žilina, 2010

[2] MADLENÁKOVÁ, L., MAJERČÁKOVÁ, M.: Legislatíva v poštových službách a elektronických komunikáciách. - 1. vyd. - Žilina : Žilinská univerzita v Žiline, 2007. - 1 elektronický optický disk (CD-ROM). - ISBN 978-80-8070-789-7.

[3] MADLEŇÁK, R. - VACULÍK, J. Elektronické podnikanie. Technológie, aplikácie a formy elektronického podnikania. Žilina : Žilinská univerzita, 2009, s. 221. ISBN 97880-8070-952-5 